\title{
Agricultural practices and content of non nutritional elements (metals traces, pesticides, and plasticizing) of truck farming in Niéki valley in the South-East of Côte d'Ivoire
}

\author{
Toure $\mathbf{N}^{1}$, Yao-Kouame A ${ }^{1}$, Alui K. A. ${ }^{1}$, Kwadjo K. E. ${ }^{1}$ \\ ${ }^{1}$ University of Cocody, UFR Sciences of Soil and Mining Resources, Department of soil \\ Sciences, 22 BP 582 Abidjan 22. \\ ${ }^{2}$ University of Abobo-Adjamé, UFR Sciences of Nature, 01 BP 3594 Abidjan 01. \\ Toure_nant@yahoo.fr (corresponding author)
}

\begin{abstract}
The objective of this study was to analyze through the cultivation and phytosanitary methods, the sanitary quality of the agricultural produce coming from garden products among the most usually consumed in the valley of Niéki. A survey was carried out and 120 truck farmers were interviewed in a random way; along an East-West transept Azaguié-Attingué-Dabou, where a strong activity of truck farming is practiced. It related to education level, type of training, agricultural practices (use or not of chemical inputs), types of crop, source of pesticides and periods of their application. Samples of plants (coretes pot, okra, spinach and eggplant) were also collected on the three sites, conditioned in polyethylene bags and analyzed at the laboratory in order to seek pesticides residues, plasticizers and metals traces. The results of investigation revealed that the majority of vegetable producers have not a sufficient knowledge on the application of pesticides, allowing them an efficient use, guaranteeing the harmlessness of these products. The various analyses of plants show the presence of some metals traces $(\mathrm{Cu}, \mathrm{Zn}, \mathrm{Cd}$ and $\mathrm{Pb})$, exceeding the tolerable thresholds as recommended by FAO. Also, pesticides residues (pyrethroids) and plasticizing (phthalate) were found in the leaves and fruits in contents definitely higher than the thresholds recommended by FAO for human consumption.
\end{abstract}

Keywords: Metal trace elements, truck farming, Niéki valley.

\section{INTRODUCTION}

In the current world agriculture context (exacerbated competition, consumers increasing requirements, precaution principles, food safety), farm produce quality is more and more required, particularly vegetable production quality (Baize, 2000). In Africa, the urban truck farming is regarded as a solution with the problems of supply vegetables of increasingly populated cities. It is a non organized activity, generating incomes and employment, practised by the vulnerable people of the urban and periurban areas (Assogba-Komlan, 2007). However, insect's attacks, plant diseases and land overexploitation prevent good productions. To eliminate these constraints, the market-gardeners use in an anarchistic and abusive way, chemical pesticides, mineral and organic fertilizers. These practices are not without danger, because it is a labour, little or not qualified, which handles delicate products (Madjouma et al., 2009). Moreover, with the absence of adequate mechanism of control, the use of the pesticides is seldom in conformity with the sanitary and environmental standards (Traoré et al., 2006). In Abidjan, economic capital of Côte d'Ivoire, urban and periurban agriculture strongly developed these last years because of the increase in the needs for a population which increased following the political crisis which has occurred since 2002. The aim of this study was to assess the sanitary quality of the market gardening the most consumed in Niéki valley. The specific objectives were as follows:

- To analyze the practices of fertilization and plant health treatments on the market gardenings.

- To identify and evaluate the non nutritional elements (residues of pesticides and heavy metals) present in these vegetables leaves and fruits.

\section{MATERIAL AND METHODS}

Description of study site: This study was carried out in the valley of Nieki located in the South-East of Côte d'Ivoire. This valley is placed in under catchment area of a surface of approximately 2.5 $\mathrm{km}^{2}$, delimited by co-ordinates $\mathrm{N}^{\circ} 25^{\prime} 48$ to $\mathrm{N} 5^{\circ} 18^{\prime}$ 
36 and W $4^{\circ} 17^{\prime} 24$ to W $4^{\circ} 13^{\prime} 48$ (Figure 1). The climate is of attieen type, with precipitations, for the first quarter 2010, varying from 0.5 to $1.2 \mathrm{~mm}$ of rain, and an average temperature of $28.3^{\circ} \mathrm{C}$. The hydrographic mode is dominated by the Agnéby river and the Ebrié lagoon. Soils are, for the most part, of peaty type. It is practised there some market gardening and banana intended for export (Touré et al., 2010). In general, the selected sites are similar to those described by Baize and Paquereau (1997) and correspond to zones slightly urbanized with almost the absence of industrial sectors.

Investigations: The surveyed zones were retained on the basis of report on the agricultural perimeters of truck farm in Niéki valley (Touré et al., 2010). A survey was carried out and 120 vegetables producers, sampled in a random way, were interviewed in Azaguié, Attingué and Dabou where vegetables production activity is highly practiced. Investigations were related to the level of schooling, type of training, farming methods (use or not of chemical inputs), crop plants, source of pesticides and pesticide application periods. The individual interviews were supplemented by talks of group interviews. In addition to the data of investigations, an inventory of the cultivated species was carried out, by specifying the type of collected organ.

Sampling: Some leaves of coretes (Corchoruus tridens ) and spinach, and fruits of okra and eggplant were collected by truck farm. For each plant species, 4 samples were taken giving 48 samples for the 3 sites (Azaguié, Attingué and Dabou). These samples were conditioned in polyethylene plastic bags for laboratory analyses.
Sample Analyze: Measurement of metal amounts $(\mathrm{Zn}, \mathrm{Pb}, \mathrm{Cu}$, and $\mathrm{Cd}$ ) was carried out by atomic absorption, after calibration of the apparatus, with standards prepared in the ammonium acetate solution.

For the pesticide residues analysis, samples of leave taken on the mature seedlings were packed in aluminum foil and were preserved in an icebox to the laboratory. The extraction of pesticide residues was achieved by means of a Soxlhet extractor with pentane as solvent. Gas chromatography coupled to a system of detection to capture of electrons (CPG/ECD) was used for compounds separation.

Statistical analyses: The data of investigation were evaluated statistically using Epi Information 3.5.1 and analyzed through the descriptive method analysis by the calculation of averages and percentage.

Results of plant organs analysis were assessed statistically using STATISTICA 7.1, through the variance analysis (ANOVA). When

a significant difference is revealed, the ANOVA is completed by the test of TUKEY, which makes it possible to identify variable significantly different from the others. The averages of the variables were separated at the threshold $\alpha<0.01$.

\section{RESULTS}

Education level: Generally, the vegetable producers interviewed were illiterate and they represent respectively $80 \%, 95 \%$ and $72.5 \%$ of the questioned farmers of Azaguié, Attinguié and Dabou (Table 1).

Table 1: Characteristics of truck farmers in the Nieki valley

\begin{tabular}{|c|c|c|c|c|}
\hline & \multicolumn{3}{|c|}{ Proportion of interviewed farmers (\%) } \\
\hline & & Azaguié & Attinguié & Dabou \\
\hline \multirow{4}{*}{ Education level } & Illiterate & 80 & 95 & 72,5 \\
\hline & Primary level & 7,5 & 5 & 7,5 \\
\hline & Secondary level & 5 & 0 & 17,5 \\
\hline & High level & 7,5 & 0 & 2,5 \\
\hline \multirow[t]{2}{*}{ Type of training } & $\begin{array}{l}\text { Technical training (agricultural training } \\
\text { centre) }\end{array}$ & 12,5 & 0 & 80 \\
\hline & Informal training (beside farmers) & 87,5 & 100 & 20 \\
\hline \multirow{2}{*}{ Agricultural practices } & use of inputs & 100 & 75 & 100 \\
\hline & Not use of inputs & 0 & 25 & 0 \\
\hline \multirow{3}{*}{ Source of pesticides } & Street sellers & 12,5 & 80 & 40 \\
\hline & Approved store & 67,5 & 0 & 17,5 \\
\hline & Retail trade on the market & 20 & 20 & 42,5 \\
\hline \multirow{3}{*}{$\begin{array}{l}\text { Pesticide } \\
\text { periods }\end{array}$} & Vegetative development & 7,5 & 42,5 & 37,5 \\
\hline & Flowering & 85 & 27,5 & 37,5 \\
\hline & Maturity & 7,5 & 30 & 25 \\
\hline
\end{tabular}


Type of training: Concerning the type of training of the farmers, the survey results reveal that $87.5 \%$ and $100 \%$ of the truck farmers respectively of Azaguié and Attinguié were formed beside other farmers (Table 1). At Dabou, $80 \%$ of the farmers were trained in a skill centre (agricultual training centre).

Agricultural practices: It has been noted that the use of pesticides and fertilizers is systematic in the whole surveyed zones. In fact, the proportion truck farmers that use inputs represent $100 \%, 75 \%$ and $100 \%$ of the questioned people respectively at Azaguié, Attinguié and Dabou. (Table 1).

Source of pesticides: Most truck farmers of Azaguié $(67.5 \%)$ buy the pesticides in approved stores. But, the one of Attinguie and Dabou acquire the pesticides besides street sellers or through the retail trade on the market (Table 1).

Pesticide application periods: The majority of vegetable producers of Azaguié (85\%) use pesticides during the flowering stage of the plants. However, at Attinguié and at Dabou, almost the same proportions of farmers use pesticides at the vegetative development, flowering and maturity of the plants (Table 1).

Comparison of the parameters qualitative of the data of the investigations: The factorial analysis of correspondence carried out on the data from various investigations in the indicated production zones reveals 3 types of information (Figure 2, Tableau 2 and Table 3). Axis 2 of inertia $32.89 \%$ reveals type I (primary education level, use of inputs, flowering and maturity), indicating that in Azaguié, producers having the primary education level use the agricultural inputs at the time of flowering and the maturity of the fruits. Axis 1 of inertia $67.11 \%$ reveals type II of information (sold by street sellers, training, sold on the markets, higher level and vegetative development), indicating that in Attinguié, the producers with less training and those having a higher level acquire their agricultural inputs beside street sellers and use them at flowering. The same axis 1 reveals the type III of information (sold in specialized stores, secondary level, agricultural training centre and not use of intrants agricultural), indicating that in Dabou, some producers having a secondary level, agricultural training centre, use the pesticides sold by specialized stores. On the other hand, others do not use pesticides for the agricultural production.
Table 2: Cosine squares of the point-lines

\begin{tabular}{|l|l|l|}
\hline & F1 & F2 \\
\hline Azaguié & 0,137 & $\mathbf{0 , 8 6 3}$ \\
\hline Attinguié & $\mathbf{0 , 7 0 6}$ & 0,294 \\
\hline Dabou & $\mathbf{0 , 9 6 2}$ & 0,038 \\
\hline
\end{tabular}

Table 3: Cosine squares of the point-columns

\begin{tabular}{|l|l|l|}
\hline & F1 & F2 \\
\hline Illiterate & $\mathbf{0 , 9 7 3}$ & 0,027 \\
\hline Primary level & 0,077 & $\mathbf{0 , 9 2 3}$ \\
\hline Secondary level & $\mathbf{0 , 9 9 8}$ & 0,002 \\
\hline High level & 0,000 & 1,000 \\
\hline agricultural training centre & $\mathbf{0 , 9 8 8}$ & 0,012 \\
\hline Informal training & $\mathbf{0 , 9 8 1}$ & 0,019 \\
\hline Input use & 0,007 & $\mathbf{0 , 9 9 3}$ \\
\hline Not input use & $\mathbf{0 , 7 4 3}$ & 0,257 \\
\hline Sold by street sellers & $\mathbf{0 , 6 8 4}$ & $\mathbf{0 , 3 1 6}$ \\
\hline Sold by approved stores & $\mathbf{0 , 6 3 7}$ & $\mathbf{0 , 3 6 3}$ \\
\hline Sold on markets & $\mathbf{0 , 9 2 9}$ & 0,071 \\
\hline Vegetative development & 0,000 & 1,000 \\
\hline Flowering & 0,189 & $\mathbf{0 , 8 1 1}$ \\
\hline Maturity & 0,197 & $\mathbf{0 , 8 0 3}$ \\
\hline
\end{tabular}

Table 4: Pesticides and plasticizer found in plant organs

\begin{tabular}{|l|l|l|}
\hline Molecules & Family & $\begin{array}{l}\text { Acceptable Daily } \\
\text { Intake } \\
\left(\text { ADI, } \mathbf{~ m g . k g} \mathbf{~}^{-\mathbf{1}} \cdot \mathbf{j}^{-\mathbf{1}} \text { ) }\right.\end{array}$ \\
\hline Bifenthrin & Pyrethroid & 0.015 \\
\hline Deltamethrin & Pyrethroid & 0.01 \\
\hline Cyhalothrin E & Pyrethroid & 0.02 \\
\hline DOP & Phthalate & 0.04 \\
\hline
\end{tabular}

\section{RESULTS OF ANALYSIS}

Pesticides and plasticizers found in plants: Chemical analysis of various plant organs (Table 4) showed that the most found elements were 
pesticides of pyrethroid family (Bifenthrin, Deltamethrin and Cyhalothrin) and one plasticizer of phthalate family (1,2- Benzènedicarboxylic acid, bis(2-ethylhexyl)ester).

Pesticides residues in plant organs: Parameters of table 2 generally indicate the presence of pyrethroids (Bifenthrin, Deltamethrin and Cyhalotrin) and of phthalate (DOP) in all the plants collected at variable contents. The amounts of Bifenthrin found in the most samples exceeded the acceptable daily intake $(0.015$ $\left.\mathrm{mg} \cdot \mathrm{kg}^{-1} \cdot \mathrm{j}^{-1}\right)$, except in okra where the amounts were below the ADI. They were respectively $0.009 \mathrm{mg} . \mathrm{kg}$ ${ }^{1} . j^{-1}$ in Azaguié, $0.008 \mathrm{mg} \cdot \mathrm{kg}^{-1} \cdot \mathrm{j}^{-1}$ in Attinguié and $0.003 \mathrm{mg} \cdot \mathrm{kg}^{-1} \cdot \mathrm{j}^{-1}$ in Dabou.

Phthalate (DOP) amounts in the plants were below the ADI $\left(0.04 \mathrm{mg} \cdot \mathrm{kg}^{-1} \cdot \mathrm{j}^{-1}\right)$ and vary from 0.008 to $0.018 \mathrm{mg} \cdot \mathrm{kg}^{-1} \cdot \mathrm{j}^{-1}$ (Table 5).

Cyhalothrin is observed only in corete pot leaves (Table 5) with an amount appreciably equal to that of the ADI $\left(0.02 \mathrm{mg} \cdot \mathrm{kg}^{-1} \cdot \mathrm{j}^{-1}\right)$. Deltamethrin amounts, in average $0,053 \mathrm{mg} \cdot \mathrm{kg}^{-1} \cdot \mathrm{j}^{-1}$, were largely over the ADI $\left(0.01 \mathrm{mg} \cdot \mathrm{kg}^{-1} \cdot \mathrm{j}^{-1}\right)$ only in corete pot leaves.
Metals traces contents in plants: Table 6 shows that metals traces found in leaves and fruits of the 4 cultivated species on the various sites of sampling are $\mathrm{Cu}, \mathrm{Pb} \mathrm{Zn}$ and $\mathrm{Cd}$. It is observed that $\mathrm{Cu}$ has tendency of accumulation in leaves and in fruits. The amounts are relatively low in okra fruits at Azaguié (4.95 $\left.\mathrm{mg} \mathrm{kg}^{-1}\right)$, Attingué $\left(7.16 \mathrm{mg} \cdot \mathrm{kg}^{-1}\right)$ and in spinach leaves at Dabou $\left(1.34 \mathrm{mg} \cdot \mathrm{kg}^{-1}\right)$. Cu contents in the various plants largely exceed the thresholds recommended by FAO $\left(1 \mathrm{mg} \cdot \mathrm{kg}^{-1}\right)$. Except low dose Cd observed in okra fruits at Azaguié $\left(0.24 \mathrm{mg} . \mathrm{kg}^{-1}\right)$, Attingué $\left(0.29 \mathrm{mg} \cdot \mathrm{kg}^{-1}\right)$ and Dabou $\left(0.12 \mathrm{mg} \cdot \mathrm{kg}^{-1}\right)$, the actual values in the other plants were relatively high and largely over tolerable threshold $\left(0.04 \mathrm{mg} \cdot \mathrm{kg}^{-1}\right)$. $\mathrm{Pb}$ contents in the various plants range between 106 and $109 \mathrm{mg} \cdot \mathrm{kg}^{-1}$ for all the three sites, largely exceeding the threshold indicated by FAO (0.1 mg. $\mathrm{kg}^{-1}$ of fresh matter). Among all the elements traces detected, $\mathrm{Zn}$ was that which accumulated more in leaves and fruits of plants. The amounts were over $506 \mathrm{mg} \cdot \mathrm{kg}^{-1}$, which largely exceeded the tolerable threshold $\left(2 \mathrm{mg} \cdot \mathrm{kg}^{-1}\right)$.

Table 5: Pesticides and phthalate contents in the plants on the various sites

\begin{tabular}{|c|c|c|c|c|c|c|}
\hline \multirow{3}{*}{$\begin{array}{l}\text { Sites of } \\
\text { study }\end{array}$} & \multicolumn{2}{|c|}{ Studied plants } & \multicolumn{4}{|c|}{ Amounts of pesticides and phthalate $\left(\mathrm{mg} \cdot \mathrm{kg}^{-1}\right)$} \\
\hline & \multirow{2}{*}{$\begin{array}{l}\text { Common } \\
\text { noun }\end{array}$} & \multirow{2}{*}{ Species } & \multirow{2}{*}{$\begin{array}{l}\text { Bifenthrin } \\
\text { (Pyrethroid) }\end{array}$} & \multirow{2}{*}{$\begin{array}{l}\text { Cyhalothrin } \\
\text { (Pyrethroid) }\end{array}$} & DOP & Deltamethrin \\
\hline & & & & & (Phthalate) & (Pyrethroid) \\
\hline \multirow{4}{*}{ Azaguié } & Pot Corete & Corchoruus tridens & $\begin{array}{l}0.021 \pm 0.00065 \\
a\end{array}$ & $\begin{array}{l}0.022 \pm 0.00085 \\
a\end{array}$ & $\begin{array}{|ll|}0.008 & \pm \\
0.000068 \mathrm{c} & \\
\end{array}$ & $\begin{array}{l}0.053 \pm 0.00095 \\
b\end{array}$ \\
\hline & Spinach & Basela alba & \multicolumn{2}{|l|}{$0.006 \pm 0.000075 b$} & \multicolumn{2}{|l|}{$0.008 \pm 0.000068 c$} \\
\hline & Okra & Abelmoschus sp & \multicolumn{2}{|l|}{$0.009 \pm 0.000087 b$} & \multicolumn{2}{|l|}{$0.008 \pm 0.000068 c$} \\
\hline & Eggplant & $\begin{array}{l}\text { Solanum } \\
\text { aethiopicum }\end{array}$ & \multicolumn{2}{|l|}{$0.019 \pm 0.00058 a$} & \multicolumn{2}{|l|}{$0.018 \pm 0.00049 \mathrm{~b}$} \\
\hline \multirow{4}{*}{ Attingué } & Pot Corete & Corchoruus tridens & $\begin{array}{l}0.020 \pm 0.00064 \\
a\end{array}$ & $\begin{array}{l}0.022 \pm 0.00065 \\
a\end{array}$ & $\begin{array}{|ll|}0.008 & \pm \\
0.000068 \mathrm{c} & \\
\end{array}$ & $\begin{array}{l}0.053 \pm 0.00095 \\
b\end{array}$ \\
\hline & Spinach & Basela alba & \multicolumn{2}{|l|}{$0.007 \pm 0.000082 b$} & \multicolumn{2}{|l|}{$0.009 \pm 0.000071 \mathrm{c}$} \\
\hline & Okra & Abelmoschus sp & \multicolumn{2}{|l|}{$0.008 \pm 0.000068 b$} & \multicolumn{2}{|l|}{$0.008 \pm 0.000068 c$} \\
\hline & Eggplant & $\begin{array}{l}\text { Solanum } \\
\text { aethiopicum }\end{array}$ & \multicolumn{2}{|l|}{$0.022 \pm 0.00069 a$} & \multicolumn{2}{|l|}{$0.018 \pm 0.00049 b$} \\
\hline \multirow{5}{*}{ Dabou } & Pot Corete & Corchoruus tridens & $\begin{array}{l}0.021 \pm 0.00065 \\
a\end{array}$ & $\begin{array}{l}0.022 \pm 0.00085 \\
a\end{array}$ & $\begin{array}{|ll|}0.009 & \pm \\
0.000071 \mathrm{c} & \\
\end{array}$ & $\begin{array}{l}0.053 \pm 0.00095 \\
b\end{array}$ \\
\hline & Spinach & Basela alba & \multicolumn{2}{|l|}{$0.057 \pm 0.00091 \mathrm{a}$} & \multicolumn{2}{|l|}{$0.009 \pm 0.000071 \mathrm{c}$} \\
\hline & Okra & Abelmoschus sp & \multicolumn{2}{|l|}{$0.003 \pm 0.000072 b$} & \multicolumn{2}{|l|}{$0.008 \pm 0.000068 c$} \\
\hline & Eggplant & $\begin{array}{l}\text { Solanum } \\
\text { aethiopicum }\end{array}$ & \multicolumn{2}{|l|}{$0.017 \pm 0.00045 a$} & \multicolumn{2}{|l|}{$0.017 \pm 0.00045 b$} \\
\hline & & $\begin{array}{l}\text { Acceptable Daily } \\
\text { Intake } \\
\text { (ADI) }\end{array}$ & $a^{0.015 \pm 0.00043}$ & $0.02 \pm 0.00085 a$ & \multirow[t]{2}{*}{$0.044 \pm 0.00081 a$} & $0.01 \pm 0.068 \mathrm{a}$ \\
\hline & & $\mathrm{F}_{\mathrm{cal}}$ & $266.47^{* *}$ & $0.31 \mathrm{NS}$ & & 134.78 ** \\
\hline & & $\mathrm{P}_{\mathrm{cal}}$ & 0 & 0.747947 & 0 & 0.001357 \\
\hline & & $P_{\text {theor }}$ & $<0.01$ & $>0.05$ & $<0.01$ & $<0.01$ \\
\hline
\end{tabular}


Am. J. Sci. Ind. Res., 2012, 3(1): 39-46

The averages followed by the same letter in the same column are not statistically different with $\mathrm{P}<0.01$ according to the test of Tukey. Cal $=$ calculated, theor $=$ theoretical

Table 6: Contents of metals traces raised in the plants on the various sites

\begin{tabular}{|c|c|c|c|c|c|}
\hline \multirow{2}{*}{$\begin{array}{l}\text { Sites of } \\
\text { study }\end{array}$} & \multirow{2}{*}{ Species } & \multicolumn{4}{|c|}{ Metal traces elements (mg. $\mathrm{kg}^{-1}$ ) } \\
\hline & & $\mathrm{Cu}$ & Zn & Cd & $\mathbf{P b}$ \\
\hline \multirow{4}{*}{ Azaguié } & Corchoruus tridens & $10.16 \pm 0.21 b$ & $95.85 \pm 5.76 a b$ & $66.57 \pm 3.97 b$ & $106 \pm 9.65 a$ \\
\hline & Basela alba & $7.62 \pm 0.18 \mathrm{bc}$ & $506.77 \pm 27.87 a$ & $11.62 \pm 0.33 b c$ & $105 \pm 9.65 a$ \\
\hline & Abelmoschus sp & $4.95 \pm 0.09 \mathrm{bc}$ & $177.95 \pm 10.11 a b$ & $0.24 \pm 0.00011 \mathrm{c}$ & $103 \pm 9.64 a$ \\
\hline & Solanum aethiopicum & $17.33 \pm 0.81 a b$ & $182.06 \pm 10.34 a b$ & $217.23 \pm 19.62 \mathrm{a}$ & $102 \pm 9.63 \mathrm{a}$ \\
\hline \multirow{4}{*}{ Attinguié } & Corchoruus tridens & $12.34 \pm 0.34 b$ & $117.68 \pm 10.06 a b$ & $12.40 \pm 0.35 b c$ & $105 \pm 9.65 a$ \\
\hline & Basela alba & $3.87 \pm 0.08 \mathrm{bc}$ & $54.23 \pm 3.78 b$ & $101 \pm 9.52 a b$ & $106 \pm 9.65 a$ \\
\hline & Abelmoschus sp & $7.16 \pm 0.16 b c$ & $367.24 \pm 21.17 a$ & $0.29 \pm 0.00028 \mathrm{c}$ & $101 \pm 9.52 \mathrm{a}$ \\
\hline & Solanum aethiopicum & $15.23 \pm 0.67 a b$ & $87.06 \pm 5.43 b$ & $101 \pm 9.52 a b$ & $108 \pm 9.68 \mathrm{a}$ \\
\hline \multirow{8}{*}{ Dabou } & Corchoruus tridens & $20.82 \pm 1.11 a$ & $183.45 \pm 10.56 a b$ & $6.45 \pm 0.14 \mathrm{bc}$ & $110 \pm 9.69 a$ \\
\hline & Basela alba & $1.34 \pm 0.009 \mathrm{c}$ & $39.47 \pm 1.89 \mathrm{bc}$ & $101 \pm 9.52 a b$ & $107 \pm 9.65 a$ \\
\hline & Abelmoschus sp & $11.44 \pm 0.32 b$ & $480.42 \pm 22.51 \mathrm{a}$ & $0.12 \pm 0.00008 \mathrm{c}$ & $109 \pm 9.68 \mathrm{a}$ \\
\hline & Solanum aethiopicum & $12.55 \pm 0.36 b$ & $64.45 \pm 5.98 b$ & $101 \pm 9.52 a b$ & $104 \pm 9.65 a$ \\
\hline & $\begin{array}{l}\text { Tolerable thresholds } \\
\text { (FAO) }\end{array}$ & $1 \pm 0.00076 \mathrm{c}$ & $2 \pm 0.00098 c$ & $0.04 \pm 0.0000012 \mathrm{~d}$ & $0.1 \pm 000072 b$ \\
\hline & $\mathrm{F}_{\text {cal }}$ & 189.32 ** & $117.91^{* *}$ & $861.43^{* *}$ & $782.56^{* *}$ \\
\hline & $\mathrm{P}_{\text {cal }}$ & 0.000087 & 0.000095 & 0.00000787 & 0.00000956 \\
\hline & $\mathrm{P}$ theor & $p<0.01$ & $p<0.01$ & $p<0.01$ & $p<0.01$ \\
\hline
\end{tabular}

The averages followed by the same letter in the same column are not statistically different with $\mathrm{P}<0.01$ according to the test of Tukey. Cal $=$ calculated, theor $=$ theoretical

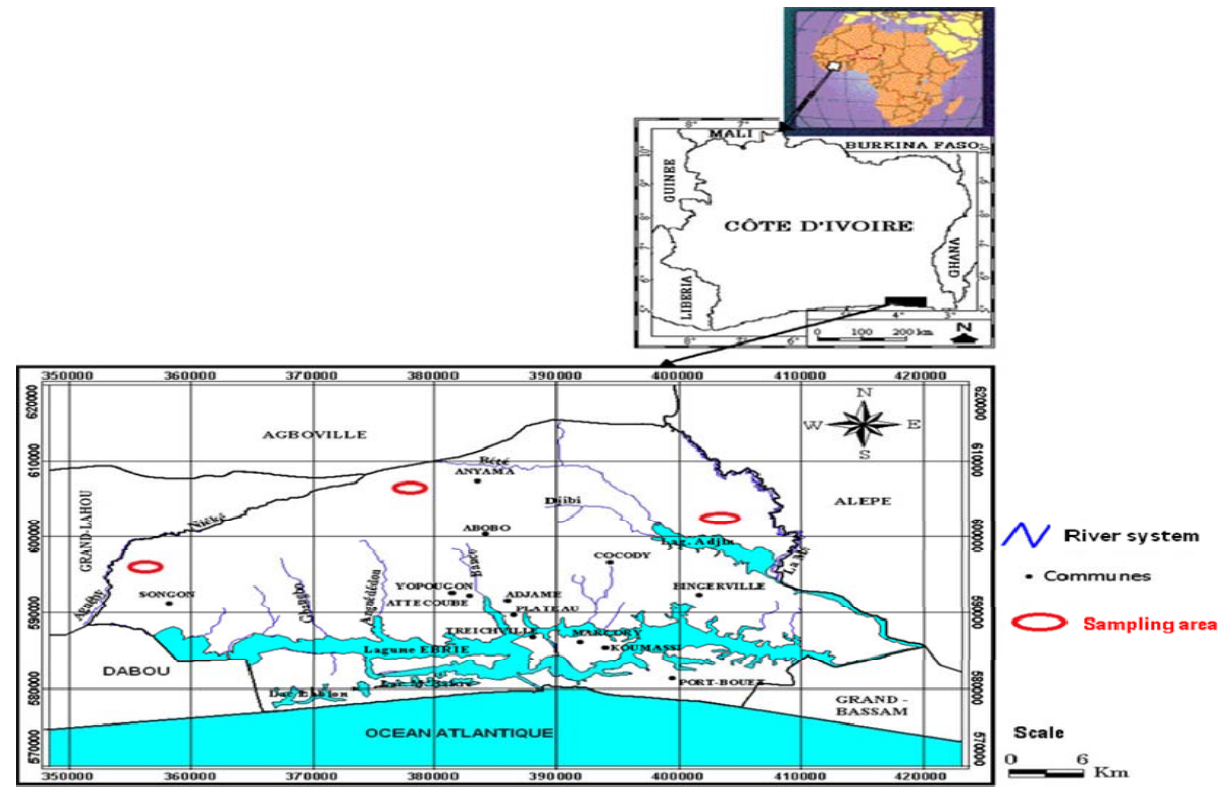

Fig 1: Localization of the various sites of studies 
Am. J. Sci. Ind. Res., 2012, 3(1): 39-46

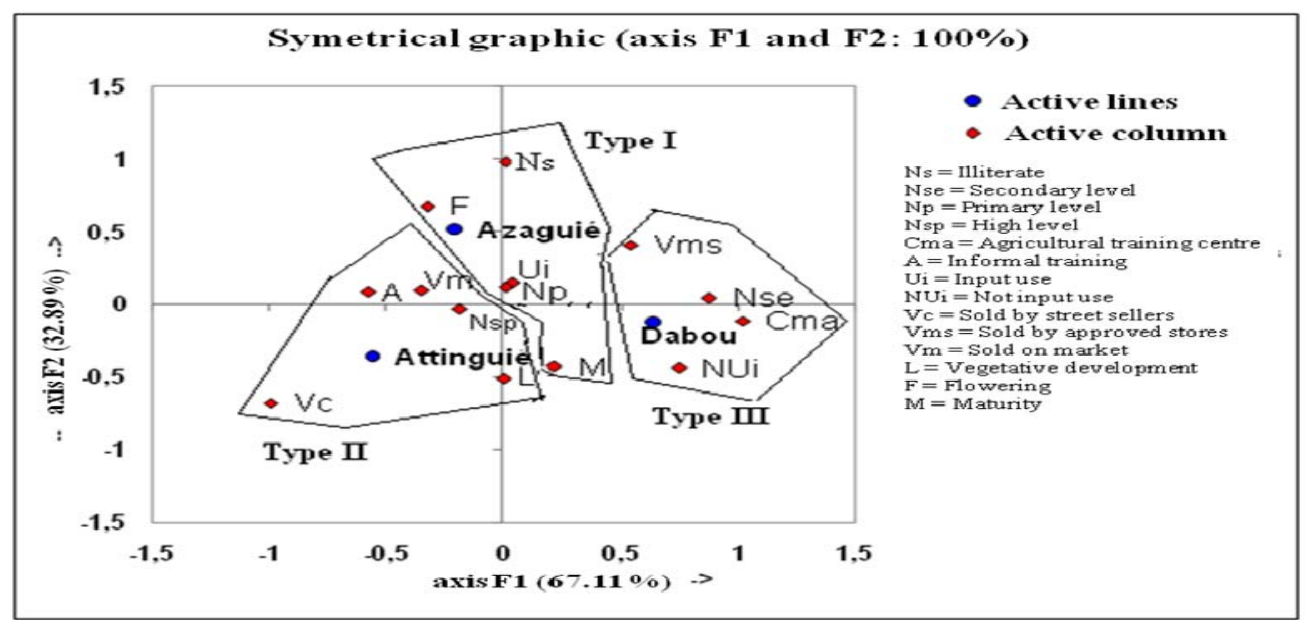

Fig 2: Factorial analysis of correspondence of the qualitative parameters of the investigations carried out on the various sites of the study.

\section{DISCUSSION}

The surveys carried out near the truck farmers indicated that major the part of them practising the truck farming were illiterate and less training. Indeed, in many african countries, in particular in Côte d'Ivoire, truck farming is a non organized activity, generating incomes and employment, practised by the vulnerable people (Moustier and Page, 1999). Investigations carried out at Azaguié, Attingué and Dabou, indicate that most of the producers use some agricultural inputs to fertilize the soil and to control the plant pests. Indeed, to meet the food needs for a great urban zone such as Abidjan, on surfaces increasingly reduced, on which are practised an intensive agriculture, truck farmers use more pesticides in order to maximize the yields (MINAGRI, 1993). The majority of vegetable producers acquire inputs beside street sellers. This behavior could be explained by the lack of adequate training or information about the pesticides that they use, or by the lack of control in the trucking field in Côte d'Ivoire (Doumbia and Kwadjo, 2009).

A great number of the surveyed truck farmers apply more than one time some pesticides on plants, which is not without danger for the plants and the environment. Thiam and Touni (2009) found the some results and conclude that in many developing country, conditions do not allow small farmers to use without danger the pesticides with high toxicity. Like that, it is noted some permanent damage as well on the farmers' health as on the environment and the cultures.
Results of pesticides and plasticizers residues analysis of the plants samples collected on the sites of Azaguié, Attingué and Dabou show the existence of the risks of contamination by pesticides. The high contents of pyrethroids and phthalate in plant samples could be explained by the inappropriate or abusive use of pesticides by illiterate farmers who could have difficulties to read the labels indicating the amounts of use and the precautions recommended, even if the pesticides used are approved in truck farming (Agossou et al., 2001).

Phthalate found in the various plants could come from the packaging used for the conditioning of pesticides, the most in plastics. Indeed, the phthalates are used to $90 \%$ as plasticizers, additions with the plastics (up to $50 \%$ of the total product mass). They give flexibility, elasticity and durability to them, which allows a great number of applications (Hand et al., 2006). The phthalates are also used like additives of glues, lubricants and pesticides. But, these products do not set in a strong way at their matrix and are released uninterrupted in their immediate environment (Marsee, 2006).

The various analyses of the plants revealed the presence of some metals traces ( $\mathrm{Cu}, \mathrm{Zn}, \mathrm{Cd}$ and $\mathrm{Pb}$ ) in leaves and fruits. That could be related to the edaphic factors through different fertilization methods (chickens droppings) and the use of pesticides (Rico, 2000) or other factors such as atmospheric repercussions, farming cycle duration, interactions between minerals, and other characteristics of the ground (Cambier, 1994; Sanka et al, 1995). These 
elements, no biodegradable, can reach, because of their high absorption by plants, to some contents prohibited for human health (Henin, 1983).

When we compare the various amounts of $\mathrm{Zn}$ and $\mathrm{Cu}$, those observed for $\mathrm{Zn}$ in the plants largely exceed the amounts of $\mathrm{Cu}$. According to KabataPendias and Pendias (2001), $\mathrm{Cu}$ and $\mathrm{Zn}$ are apparently absorbed by the same mechanism and their combined presence in the soil can limit their absorption (Leblanc and Châteauneuf, 2003; TremelSchaub and Feix, 2005). However the high contents of $\mathrm{Zn}$ recorded in the plants of the 3 sites shows that $\mathrm{Zn}$ is easily biodisponible in the soils light and acid (Bisson et al., 2005), but the majority of the soils where these truck farming are established are more acid (Touré et al., 2010).

\section{CONCLUSION}

The most truck farmers of the Niéki valley have not a sufficient level of knowledge on the use of pesticides allowing them an efficient use, respecting the standards of consumption and environment.

The contents of pesticides (pyrethroids), plasticizer (DOP) and metal traces elements $(\mathrm{Cd}, \mathrm{Zn}, \mathrm{Cu}$ and $\mathrm{Pb}$ ) found in the plants were higher than the Acceptable Daily Intake (ADI).

To control the contamination in pesticides residues, plasticizers and metals traces of the truck farming species cultivated in the Niéki valley, we recommend, first, the sprinkle the plants with clean water (running water); in second time, the replacement of the poultry droppings by other types less polluting and finally the sensitizing and the training of the truck farmers on the good agricultural pratises.

\section{REFERENCES}

Assogba-Komlan, F., Anihouvi, P., Achigan, E., Sikirou, R., Boko, A., Adje, C., Ahle, V., Vodouhe, R., Assa, A. (2007). Pratiques culturales et teneur en éléments anti nutritionnels (nitrates et pesticides) du Solanum macrocarpum au sud du Bénin. African journal of food agriculture nutrition and developement. Volume $7 n^{\circ} 4$ ISSN: 1684-5374.

Baize, D. (2000). Teneurs totales en " métaux lourds " dans les sols français résultats, généraux du programme ASPITET. INRA, unité de Science du sol, centre d'Orléans, Ardon. Le Courrier de l'environnement $n^{\circ} 39$.

Baize, D. et Paquereau, H. (1997). Teneurs totales en élém ents traces dans les sols agricoles de Seine et Marne. Étude et Gestion des Sols, 2, pp. 77 - 93.

Bisson, M., Diderich, R., Hulot, C., Houeix, N., Lacroix, G., Lefèvre, J.P., Leveque, S., Magaud, H. et Morin, A.
(2005). Fiche de données toxicologiques et environnementales des substances chimiques. Zinc et ses dérivées, $69 \mathrm{p}$.

Cambier, P. (1994). Contamination of soils by heavy metals and other trace elements: a chemical perspective. Anal. Mag., 22 (2) : 21-24.

Doumbia, M. et Kwadjo, K.E. (2009). Pratiques d'utilisation et de gestion des pesticides par les maraîchers en Côte d'Ivoire : Cas de la ville d'Abidjan et deux de ses banlieues (Dabou et Anyama). Journal of Applied Biosciences $n^{\circ} 18$, pp 992-1002.

Henin, S. ( 1983). Les éléments traces dans le sol. Sci. Sol., 2 : 67-71.

Kabata-Pendias, A. and Pendias, H. ( 2001). Trace elements in soils and plants. Third Edition. CRC Press, $413 \mathrm{p}$.

Leblanc, R. et Châteauneuf, G. (2003). Restauration des sols contaminés par phytorémédiation. Rapport final, $81 \mathrm{p}$.

Madjouma, K., Kpérkouma, W., Komlan, B., Gbandi, D. B. et Adam, A. K.A. (2009). Le maraîchage périurbain à Lomé : pratiques culturales, risques sanitaires et dynamiques spatiales. Cahiers Agricultures. Volume 18, Numéro 4, 356-363.

Main, K.M., Mortensen, G.K., Kaleva, M.M., Boisen, K.A., Damgaard, I.N. and Chellakooty, M. (2006). Human breast milk contamination with phthalates and alterations of endogenous reproductive hormones in infants three months of age. Environ Health Perspect 114(2):270-276.

Marsee, K,. Woodruff, T.J., Axelrad, D.A., Calafat, A.M. and Swan, S.H. (2006). Estimated daily phthalate exposures in a population of mothers of male infants exhibiting reduced anogenital distance. Environ Health Perspect 114(6):805-809.

Moustier, P. et Page J. (1999). Le périurbain en Afrique : une agriculture en marge ? In : Courrier de l'Environnement $\mathrm{N}^{\circ} 32$. CIRAD, Montpellier.

Olanrewaju, B., Moustier, P., Mougeot, L.J.A. et Abdou, F. (2004). Développement durable d'une agriculture urbaine en Afrique francophone; enjeux concepts et méthodes. CIRAD/CRDI, $176 \mathrm{p}$.

Rico, A. (2000). Pollutions et pratiques agricoles. Deux concepts: dose journalière admissible et chimiodéfense. C.R. Acad. Sci. Paris, Sciences de la vie : 323, 435-440.

Sanka, M., Strnad, M., Vondra, J. and Paterson, E. (1995). Sources of soil and plant contamination in an urban environment and possible assessment methods. Int. J. Environ. Anal. Chem., 59 : 327-343.

Temple, L. et Moustier, P. (2004). Les fonctions et contraintes de l'agriculture périurbaine de quelques 
Am. J. Sci. Ind. Res., 2012, 3(1): 39-46

villes africaines (Yaoundé, Cotonou, Dakar). Cah Agric $2004 ; 13: 15-22$.

Thiam, M. and Touni, E. (2009). Pesticide poisoning in West Africa. Pesticides News PAN UK n 85 pp 3-4.

Touré, N., Yao-Kouamé, A., Alui, K. A. et Guety, T. P. (2010). Evaluation en éléments majeurs et traces métalliques d'un environnement de production agricole dans la vallée du Niéki au Sud-est de la Côte d'Ivoire. Journal of Applied Biosciences 34: 2134 - 2144. ISSN 1997-5902.
Traore, S.K., Mamadou, K., Dembele, A., Lafrance, P., Mazellier, P. et Houenou, P. (2006). Contamination de l'eau souterraine par les pesticides en régions agricoles en Côte d'Ivoire (centre, sud et sud ouest). Journal Africain des Sciences de l'Environnement, , Numéro 1, 1-9.

Tremel-Schaub, A. et Feix, I. (2005). Contamination des sols : Transferts des sols vers les plantes. EDP Sciences, ADEME, $416 \mathrm{p}$. 